\title{
Dilema dalam Kebijakan Negara dan Keamanan Manusia: Kasus Kebijakan India pada Pemerintahan Narendra Modi, Perdana Menteri India
}

\author{
Alrafsya Mahendra Saputra \\ 2014330110 \\ Mahasiswa Ilmu Hubungan Internasional, Fakultas Ilmu Sosial dan Ilmu Politik \\ Universitas Katolik Parahyangan
}

\begin{abstract}
India is a country that is known for its attachment to its culture, but on the other hand, what is unknown to the wider community is the existence of human rights violations caused by its own government under the leadership of Narendra Modi. What the author will say in this case is about Narendra Modi's policy in solving social and economic welfare issues. His welfare policy is how he resolves social conflicts, social security, and his economic policies to be examined is how he promoted India as an industrialist state can undermine the protection of his human rights.
\end{abstract}

Keywords: Narendra Modi, digital india, Make in India, poverty, modern slavery

India dikenal sebagai negara yang mempunyai keterikatan terhadap kultur dan agama yang sangat tinggi. Bahkan, karena keterikatan ini, di era modern pun budaya masih melekat dalam kehidupan sosial mereka. Hidup dalam komunitaskomunitas, dan hubungan kekeluargaan yang erat, dan bahkan mempunyai kasta yang sangat berpengaruh terhadap kehidupan sosialnya. Namun yang perlu diketahui juga di dalam negara yang terikat dengan budayanya, negara ini juga sedang mengalami permasalahan dalam aspek kemanusiaan.

Uniknya, awal dari permasalahan ini dimulai dari pemerintahan yang dipimpin oleh Narendra Modi, Perdana Menteri India. Sosok ini menjadi sangat penting dalam pembahasan, dan menjadi sosok yang kontroversial jika berhubungan dengan aspek kemanusiaan. Salah satu kejadian yang membuat kredibilitas dia dipertanyakan dalam aspek menjaga keamanan kemanusiaan adalah kerusuhan Gujarat, kejadian yang menggambarkan adanya gerakan anti muslim di

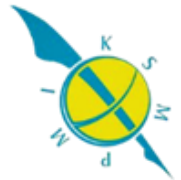


negara India yang menyebabkan banyaknya korban (dikarenakan populasi orang muslim di India tidaklah besar) dan sosok Modi inilah yang dituduh sebagai pelopor yang menyebabkan kejadian tersebut. ${ }^{1}$ Sehingga sampai saat ini sosok secara internasional dan secara domestik masih dapat dikatakan sebagai sosok yang kontroversial.

Secara internasional, India di bawah naungan Narendra Modi juga sudah dikenal sebagai negara yang masih mempunyai konsiderasi yang kecil terhadap masalah human security. Seperti di saat Narendra Modi bertemu dengan Amerika, salah satu senat di Amerika Serikat menyinggung masalah kemanusiaan yang harus dibenahi seperti pekerja-pekerja yang terpaksa dalam industri-industri dan perdagangan seks yang masih terjadi di India. ${ }^{2}$ Tulisan ini tidak akan hanya membahas masalah-masalah kemanusiaan yang terjadi di India di bawah naungan Narendra Modi, namun akan mendalami juga bagaimana program dan kebijakan yang dibuat oleh Narendra Modi yang sangat berbasis visinya memodernisasi India, menjadi salah satu faktor penting bagaimana human security dalam India sedang dalam masalah.

Sebelum masuk kepada kasus, penulis akan mengemukakan konsep human security. Penulis akan mengambil konsep tersebut dari penjelasan dipublikasikan oleh Perhimpunan Bangsa- Bangsa mengenai human security. Definisi yang dikemukakan oleh United Nations adalah to protect the vital core of all human lives in ways that enhance human freedoms and human fulfillment. ${ }^{3}$ Artinya adanya melindungi kebebasan manusia untuk mempertahankan hidupnya dan memenuhi kebutuhan hidupnya. Artinya setiap negara sudah seharusnya mempunyai tanggung jawab untuk melindungi rakyatnya untuk memenuhi

\footnotetext{
1 "Profile: Narendra Modi", BBC, 11 November, 2015, diakses pada tanggal 27 November 2017, http://www.bbc.com/news/world-asia-india-20001001

2 Annie Gowen, "U.S. senators attack India's human rights record before Modi's Capitol Hill address", Washington Post, 1, juni, 2016, diakses pada tanggal 27 November 2017, https://www.washingtonpost.com/news/worldviews/wp/2016/06/01/u-s-senators-attackindias-human-rights-record-before-modis-capitol-hill-address/?utm_term=.132358fbeda2

${ }^{3}$ Human Security In Theory And Practice, (United Nation: 2009), 5
}

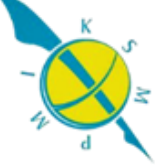


kebutuhannya. Dalam kasus ini kebijakan India sudah seharusnya mempunyai kebijakan-kebijakan yang mendukung rakyatnya.

Menurut bukunya ada beberapa sifat dari human security: people oriented, multi- sectoral, comprehensive, context specific, dan prevention oriented. Sifatsifat ini yang akan menjadi tolak ukur kebijakan-kebijakan Narendra Modi yang berhubungan dengan ${ }^{4}$ modernisasi India, bahwa kebijakannya akankah selaras dengan masyarakat, apakah kebijakan tersebut selaras dengan hak asasi manusia dan akhirnya menjaga rakyatnya untuk memenuhi kebutuhan hidupnya.

Narendra Modi sudah mempunyai pengalaman yang lama dalam partisipasinya politik India. Narendra Modi adalah perdana menteri India semenjak tahun 2014, ia juga menduduki sebagai ketua dari Bharatiya Janata Party (BJP) salah satu partai terbesar di India. Di tahun 2001 ia menjadi menteri utama (chief minister) di Gujarat. Semasa ia menduduki menteri di Gujarat ia dapat dikatakan membangun ekonomi menjadi kekuatan pusatnya. Namun di sisi lain ia dianggap telah melanggar hak asasi kemanusiaan, Ia dituduh seagai pelopor dalam kerusuhan Gujarat yang membiarkan aksi-aksi kekerasan terjadi, dan akhirnya menyebabkan 1000 orang meninggal yang sebagian besarnya adalah orang- orang Muslim. ${ }^{5}$

Dalam masa jabatanya, ia selalu mempunyai visi dan tujuan, secara umum ia ingin memordenisasikan India. Membangun India dalam aspek ekonomi dan pembangunan seperti contohnya meningkatkan kebersihan India dan membuat digital India adalah tujuannya ${ }^{6}$ untuk 2022. Semenjak ia untuk menduduki status tersebut, ia mempunyai visi yang sangat revolusioner untuk India yang lebih modern. Dikarenakan hal ini, dalam pemilihanya ia mendapat pendukung yang

\footnotetext{
${ }^{4}$ Ibid, 6-7

5 "Profile: Narendra Modi", BBC, 11 November, 2015, diakses pada tanggal 27 November 2017, http://www.bbc.com/news/world-asia-india-20001001

${ }^{6}$ Ibid
} 
banyak dari pelaku-pelaku bisnis yang menurutnya sangat berpotensi untuk peningkatan ekonomi India dan program-program yang akan dijalaninya. ${ }^{7}$

Semasa jabatannya, ada beberapa kebijakan untuk menjalani visinya, dan salah satu kebijakannya adalah kebijakan domestik yang berfokus kepada pembangunan India secara ekonomi dan industrialis, yaitu kebijakan Make in India yang ia janjikan kepada rakyatnya saat masa kampanye untuk menjadi perdana menteri di tahun 2014. Kebijakan ini berfokus untuk meningkatkan ketertarikan investasi-investasi asing terhadap negara India. Pemerintah India akan mengurangi larangan-larangan dan hambatan-hambatan investasi asing. Ia juga mendorong perusahaan-perusahaan domestik dan multinasional untuk meningkatkan penjualan produk-produknya di India. ${ }^{8}$ Salah satu tujuan yang ingin dicapai oleh Narendra Modi adalah meningkatkan daya saing India secara global. ${ }^{9}$

Fokus dari program Make in India ini ada 25 sektor yang berhubungan dengan industri dan mereka adalah; automobile, mesin elektrik, pengolahan makanan, tekstil dan pakaian, pelabuhan kulit, media dan hiburan, kesehatan, pertambangan, pariwisata dan perhotelan, perkeretaapian, komponen mobil, energi terbarukan, bioteknologi, ruang angkasa, tenaga termal, jalan raya dan jalan raya dan sistem elektronik. ${ }^{10}$ Jika dilihat bisa dikatakan bahwa semua ini memiliki hubungan dengan penarikan ketertarikan investor, meningkatkan fasilitas, meningkatkan sumber daya alam dan sumber manusianya, dan bahkan meningkatkan fitur komersil. Menurut perdana menteri India, India sebenarnya

\footnotetext{
7 "Narendra Modi's vision of a 'new India' is being tested", Financial Times, 16 Oktober 2017, diakses pada tanggal 27 November 2017, https://www.ft.com/content/f4da3168-948211e7-83ab-f4624cccbabe

${ }^{8}$ Raija Panicker, "As Modi Government Completes 3 Years, Its Top Five Policy Moves", NDTV, $26 \mathrm{Mei}, 2017$, diakes pada tanggal 28 November 2017, https://www.ndtv.com/indianews/as-narendra-modi-government-completes-3-years-its-top-five-policy-moves-1704118

9 "National Manifacturing", Make In India, diakes pada tanggal 28 November 2017 http://www.makeinindia.com/policy/national-manufacturing

10 "Make In India", India Brand Equity Foundation, May 2016, diakes pada tanggal 28 November 2017 https://www.ibef.org/economy/make-in-india
} 
mempunya potensi-potensi yang baik dalam aspek-aspek tersebut sehingga sangat baik jika negara ini meningkatkan potensi-potensi tersebut. ${ }^{11}$

Walaupun kebijakan Make In India terlihat sangat menjanjikan dan sangat positif sehingga sangat menarik banyak perhatian dari aktor-aktor bisnis, namun ada permasalahan terhadap implementasi dari kebijakan ini. Sehingga yang tujuannya untuk meningkatkan ekonomi India namun hasilnya memperburuk keadaannya. Inilah masalah yang ditimbulkan oleh program dari Narendra Modi.

Meningkatnya tingkat pengangguran dibandingkan dengan menurunkannya. Faktanya, pengangguran naik dari 3.8 persen menjadi 5 persen. Dikarenakanya pemerintah gagal dalam mensubsidi industri-industri lokal. Sehingga industriindustri juga lambat dalam berkompetisi dalam pasar dan akhirnya belum bisa menyediakan lapangan kerja yang tinggi, oleh karena itu masih banyak pengangguran yang terjadi di India walaupun kebijakan ini sudah mulai dijalankan. ${ }^{12}$ Bahkan di tahun 2016, negara ini masih belum bisa menyelesaikan masalah penganggurannya, titik penganggurannya masih meningkat bahkan sampai 7 persen. ${ }^{13}$ Sebagai contohnya, dalam sektor Information Technlogy (IT) yang dijanjikan menjadi salah satu dari fokus dari kebijakan Make In India, keahlian orang- orang India yang belum bisa memumpuni syarat-syarat yang dibutuhkan oleh perusahaan-perusahaan, oleh karena itu beberapa perusahaan seperti contohnya Wipro, Cognizant and Infosys mempunyai kebijakan bahwa mereka akan downsized / menurunkan lapangan pekerjaannya, dikarenakan dibandingkan mereka memakai banyak orang mereka hanya memakai beberapa orang dengan kualitas yang

\footnotetext{
${ }^{11}$ Ibid

12 "Unemployment is Up Because 'Make in India', Other Official Schemes Aren't Working”, The Wire, 13 Juni, 2017, diakes pada tanggal 28 November 2017 https://thewire.in/14725/unemployment-make-in-india-modi-schemes/

13 "Make In India has failed, unemployment highest in last 8 years: Rahul Gandhi again attacks PM Modi", Daily News and Analysis, Agustus 17, 2017, diakes pada tanggal 28 November $2017 \quad$ http://www.dnaindia.com/india/report-make-in-india-has-failedunemployment-highest-in-last-8-years-rahul-gandhi-again-attacks-pm-modi-2532714
} 
mencapai syarat. ${ }^{14}$ Dalam sumber yang sama mengatakan bahwa sebenarnya kebijakan ini tidak selaras dengan kepentinganya masyarakat India, perusahaanperusahaan akan lebih memakai AI (Artificial Inteligince) dibandingkan pekerjapekerja India. ${ }^{15}$ Sehingga kredibilitas dari program ini dipertanyakan dan dikritisi oleh Rahul Gandhi, wakil presiden dari kongres India. ${ }^{16}$ Uniknya lagi, dengan adanya program ini juga bukannya menunjukkan bahwa pertumbuhan ekonominya tidak sebaik sebelum adanya program yang dikampanyekan oleh India di bawah perdana menteri.

Dikarenakan gagalnya pemerintah dan kebijakannya yang tidak selaras dengan kebutuhan masyarakat India, maka dari itu, akhirnya tingkat dari pengangguran masih meningkat dan pertumbuhan ekonomi pun tidak meningkat. Akhirnya masalah ini merambat sampai kepada masalah-masalah sosial yang sangat berhubungan dengan kemanusiaan, hal ini dikarenakan setiap masyarakat walaupun tidak bisa mendapat pekerjaan, mereka tetap harus bertahan hidup. Hal inilah yang menyebabkan mengapa masih banyak masalah kemanusiaan di India, yaitu dikarenakan pengangguran yang belum bisa di selesaikan oleh pemerintah India. Masalah kemanusiaan yang masih sangat beredar di India adalah mengenai perbudakan modern, perbudakan modern yang dimaksud termasuk pekerjaan domsetik, konstruksi, industri seks, agrikultur, perikanan, manufaktur, manual labour, and pengemis yang dipaksa (forced begging). India menjadi salah satu peringkat tertinggi secara global dalam masalah kemanusiaan, perbudakan modern. ${ }^{17}$ Alasan mengapa suatu tindakan dikatakan sebagai perbudakan modern

14 Arpita Mukherjee dan Avantika Kapoor, "Is India on the Verge of an Unemployment Crisis?", National Interest, 5 Juni 2017, diakes pada tanggal 28 November 2017 http://nationalinterest.org/blog/the-buzz/india-the-verge-unemployment-crisis-2100

${ }^{15}$ Ibid

16 "Make In India has failed, unemployment highest in last 8 years: Rahul Gandhi again attacks PM Modi", Daily News and Analysis, Agustus 17, 2017, diakes pada tanggal 28 November $2017 \quad$ http://www.dnaindia.com/india/report-make-in-india-has-failedunemployment-highest-in-last-8-years-rahul-gandhi-again-attacks-pm-modi-2532714

${ }_{17}$ Rakkhi Mazumdar, "India has 18 million modern-day slaves: Survey", The Economic Times, 31 Mei, 2016, diakes pada tanggal 28 November 2017 
adalah adanya tekanan yang berlebihan, bahkan sampai pada titik memaksa menggunakan ancaman. Sehingga tidak ada kebebasan seseorang untuk memilih suatu pekerjaan atau melakukan sesuatu. Di tahun 2016, India yang terikat dengan aktivitas seperti itu mencapai 18 juta orang, dan 51 persen rentan terhadap aktivitas tersebut. Salah satu bentuk perbudakan modern adalah pemaksaan anak-anak agar bekerja keras untuk membayar hutang-hutang orang tuanya. Pekerja-pekerja domestik yang dikategorikan dalam perbudakan modern ini bukan pekerja umum, namun pekerja- pekerja yang mengalami siksaan. ${ }^{18}$ Untuk masalah ini, India belum bisa menyelesaikan masalahnya.

Alasan mengapa India bisa mencapai pada titik itu adalah dikarenakan penganggurannya yang sangat tinggi. Jika dilihat di bagian sebelumnya bahwa kegagalan pemerintah dalam menjalankan programnya atau programnya berjalan namun tidak sesuai dengan masyarakat India, yang menyebabkan yang akhirnya pengangguran meningkat, bahkan sampai 2017 ini data menyatakan bahwa 65 persen dari pekerja IT tidak bisa dilatih lagi untuk kemajuan teknologi yang lebih maju dapat mengancam perekonomian India. ${ }^{19}$ Kondisi-kondisi yang seperti ini yang akhirnya menyebabkan terjadinya perbudakan industri, dimana orang-orang ini harus mencari pendapatan untuk bertahan hidup.

Kesimpulannya, kebijakan dari pemerintahan Narendra Modi dapat memengaruhi human security masyarakat India. Kebijakan India dalam membangun India dalam aspek eknomi seperti Make in India yang membantu beberapa sektor (lebih tepatnya 25 sektor) sebenarnya mendapatkan pandangan yang positif dari berbagai kalangan, terutama dari kalangan pebisnis. Namun akhirnya tidak seperti

https://economictimes.indiatimes.com/news/politics-and-nation/india-has-18-millionmodern-day-slaves-survey/articleshow/52518141.cms

18 "Global Slavery Index 2016: india", Global Slavery Index, https://www.globalslaveryindex.org/country/india/

https://www.globalslaveryindex.org/country/india/

19 Venkat T., Srividya Tadepalli \& Thomas Manuel, "The Life of Labour: 65\% of Indian IT workers 'Not Trainable', Sustained Unemployment Threatens Economy", The Wire, 8 Oktober, 2017, diakes pada tanggal 28 November 2017, https://thewire.in/185414/job-lossunemployment-gst-demonetisation/

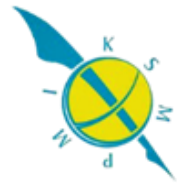


kenyataannya, kebijakan ini tidak berjalan sesuai rencana banyak sektor yang dipengaruhi oleh kebijakan ini contohnya sektor IT (Teknik Informatika) dimana kebijakan ini dapat menarik perhatian dari negara-negara besar. Namun untuk masyarakatnya, kebijakannya ini belum bisa memenuhi kebutuhannya, mereka belum bisa memenuhi syarat-syarat dari perusahaan-perusahaan. Hal ini menyebabkan pemerintah India belum bisa menyelesaikan masalah yang sangat penting di India yaitu pengangguran. Bahkan di masa jabatan Narendra Modi sebagai perdana menteri masalah ini justru meningkat, Dikarenakan masalah ini belum terselesaikan, permasalahannya merambat kepada masalah kemanusiaan lainnya yaitu perbudakan modern (modern slavery). Masalah perbudakan ini meningkat dikarenakan banyak orang masih terikat kepada pengangguran dan mereka sebagai manusia harus bertahan hidup dan mereka akan mencari pekerjaan apapun untuk bertahan hidup. Hal inilah yang menyatakan bahwa sangat penting untuk pemerintah untuk memperhatikan implikasi dari kebijakannya dikarenakan kondisi di India yang sangat kritis. Mungkin terlihat bahwa kebijakannya sangat pro-rakyat dan optimistik, namun aplikasinya belum selaras, dan hal tersebut akan sangat berpengaruh pada kondisi masa depan India.

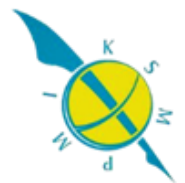




\section{Daftar Pustaka}

"Global Slavery Index 2016: india." Global Slavery Index. https://www.globalslaveryindex.org/country/india/

"Make In India has failed, unemployment highest in last 8 years: Rahul Gandhi again attacks PM Modi”. Daily News and Analysis. Agustus 17, 2017. diakes pada tanggal 28 November 2017. http://www.dnaindia.com/india/reportmake-in-india-has-failed-unemployment-highest-in-last-8-years-rahulgandhi-again-attacks-pm-modi-2532714

"Make In India has failed, unemployment highest in last 8 years: Rahul Gandhi again attacks PM Modi”. Daily News and Analysis. Agustus 17, 2017. diakes pada tanggal 28 November 2017. http://www.dnaindia.com/india/reportmake-in-india-has-failed-unemployment-highest-in-last-8-years-rahulgandhi-again-attacks-pm-modi-2532714

“Make In India.” India Brand Equity Foundation, May 2016. diakes pada tanggal 28 November 2017. https://www.ibef.org/economy/make-in-india

"Narendra Modi's vision of a 'new India' is being tested". Financial Times. 16 Oktober 2017. diakses pada tanggal 27 November 2017. https://www.ft.com/content/f4da3168-9482-11e7-83ab-f4624cccbabe

"Profile: Narendra Modi”. BBC. 11 November, 2015. diakses pada tanggal 27 November 2017. http://www.bbc.com/news/world-asia-india-20001001 "Unemployment is Up Because 'Make in India', Other Official Schemes Aren't Working." The Wire. 13 Juni, 2017. diakes pada tanggal 28 November 2017. https://thewire.in/14725/unemployment-make-in-india-modi-schemes/

Gowen, Annie. "U.S. senators attack India's human rights record before Modi's Capitol Hill address". Washington Post. 1, juni, 2016. diakses pada tanggal 27 November 2017. https://www.washingtonpost.com/news/worldviews/wp/2016/06/01/u-s-senators-attack-indias-human-rights-recordbefore-modis-capitol-hill-address/?utm_term=.132358fbeda2

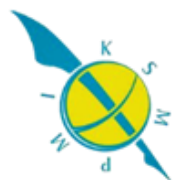


Human Security In Theory And Practice. New York: United Nation, 2009

Mazumdar, Rakhir. "India has 18 million modern-day slaves: Survey." The Economic Times. 31 Mei, 2016. diakes pada tanggal 28 November 2017. https://economictimes.indiatimes.com/news/politics-and-nation/india-has-18$\underline{\text { million-modern-day-slaves-survey/articleshow/52518141.cms }}$

Mukherjee, Arpita dan Kapoor, Avantika. "Is India on the Verge of an Unemployment Crisis?" National Interest. 5 Juni 2017. diakes pada tanggal 28 November 2017. http://nationalinterest.org/blog/the-buzz/india-the-verge$\underline{\text { unemployment-crisis-2100 }}$

National Manifacturing”. Make In India. diakes pada tanggal 28 November 2017. http://www.makeinindia.com/policy/national-manufacturing

Panicker Raija. “As Modi Government Completes 3 Years, Its Top Five Policy Moves”. NDTV. 26 Mei, 2017. diakes pada tanggal 28 November 2017, https://www.ndtv.com/india-news/as-narendra-modi-government-completes3-years-its-top-five-policy-moves-1704118

Venkat T., Srividya Tadepalli \& Thomas Manuel."The Life of Labour: 65\% of Indian IT workers 'Not Trainable', Sustained Unemployment Threatens Economy." The Wire. 8 Oktober, 2017. diakes pada tanggal 28 November 2017. https://thewire.in/185414/job-loss-unemployment-gst-demonetisation/ 